\title{
Role of a pharmacist in the safe self-medication - A questionnaire-based survey
}

\author{
Selma Škrbo ${ }^{1}$, Semir Mehović ${ }^{1}$, Naida Omerović ${ }^{1}$, Anela Hadžifejzović-Trnka ${ }^{2}$, Nermina \\ Žiga-Smajić ${ }^{1}$, Belma Pehlivanović ${ }^{1}$, and Dina Lagumdžija ${ }^{1}$ \\ ${ }^{1}$ University of Sarajevo \\ ${ }^{2}$ Amsal Pharmaceuticals d.o.o.
}

August 3, 2020

\begin{abstract}
Introduction: Self-medication has been very popular and globally prevalent for a long time. Aim: This research aims to present pharmacists' engagement in the process of self-medication in the Sarajevo Canton. Methods: A total of 312 respondents completed an anonymous questionnaire-based survey. The first group (165 respondents) was surveyed in the pharmacy after buying a non-prescription drug, and the second group (147 respondents) outside the pharmacy. Results: The most commonly purchased drug was paracetamol, whereas headache was dominant amongst health conditions for which treatment respondents intended to use the purchased drug. A belief that respondents could cure themselves was the most common answer when asked why they had not visited a doctor, whereas previous experience with the purchased drug prevailed as an answer when asked from whom they had gotten information about the adequacy of the purchased drug for their health problem. Respondents mostly bought drugs for themselves. Pharmacists instructed $65 \%$ of respondents on how to take the purchased drug and checked whether $55 \%$ of respondents bought an appropriate drug for their health problem. Only $25 \%$ and $29 \%$ of respondents were informed about the adverse effects and potential contraindications or interactions of the purchased drug, respectively. According to $45 \%$ of respondents, pharmacists spent up to one minute in a conversation with them about the purchased drug. Conclusion: In the Sarajevo Canton, pharmacists should be more actively involved in the process of self-medication and provide the necessary advice to patients consuming non-prescription drugs. Further research is needed to create a clearer picture.
\end{abstract}

Title: Role of a pharmacist in the safe self-medication - A questionnaire-based survey

Running (short) title: Role of a pharmacist in the safe self-medication

Selma Škrbo ${ }^{1}$, Semir Mehović ${ }^{1} 11$ Present address: Public institution,,Apoteke Sarajevo“, Sarajevo, Bosnia and Herzegovina, Naida Omerović ${ }^{1}$, Anela Hadžifejzović-Trnka ${ }^{2}$, Nermina Žiga-Smajić ${ }^{1}$, Belma Pehlivanović $^{1}$, Dina Lagumdžija ${ }^{1}$

${ }^{1}$ Faculty of Pharmacy, University of Sarajevo, Sarajevo, Bosnia and Herzegovina

${ }^{2}$ Amsal Pharmaceuticals d.o.o., Vogošća, Bosnia and Herzegovina

Selma Škrbo, selma.skrbo@ffsa.unsa.ba, ORCID: 0000-0001-5738-9588

Semir Mehović, semir.mehovic1989@gmail.com, ORCID: 0000-0002-9857-6774

Naida Omerović, naida.omerovic@ffsa.unsa.ba, ORCID: 0000-0002-5588-9973

Anela Hadžifejzović-Trnka, anelahadzifejzovic@ffsa.unsa.ba, ORCID: 0000-0002-9691-7440

Nermina Žiga-Smajić, nermina.ziga@ffsa.unsa.ba, ORCID: 0000-0002-4659-4268 
Belma Pehlivanović, belma.pehlivanovic@ffsa.unsa.ba, ORCID: 0000-0002-1574-493X

Dina Lagumdžija, dina.fetahovic@ffsa.unsa.ba, ORCID: 0000-0002-8042-1643

Correspondence: Naida Omerović, MPharm

Department of Clinical Pharmacy, Faculty of Pharmacy, University of Sarajevo, Zmaja od Bosne 8, 71000 Sarajevo, Bosnia and Herzegovina.

Email: naida.omerovic@ffsa.unsa.ba

Phone number: +38733586193

ORCID: https://orcid.org/0000-0002-5588-9973

\section{ACKNOWLEDGEMENTS}

There was no source of funding for this research and its publication. The authors are very grateful to all subjects who participated in this research and to the director and employees of the pharmacy where this research was carried out for providing the necessary facility.

\section{DISCLOSURES}

Conflict of interest: The authors declare that there was no conflict of interest that could be perceived as prejudicing the impartiality of this research.

Financial support and sponsorship: The authors declare that there was no financial support and sponsorship and that this research did not receive any specific grant from funding agencies in the public, commercial, or not-for-profit sectors.

\section{AUTHOR CONTRIBUTIONS}

Selma Škrbo, concept/design, data collection, data analysis/interpretation, critical revision of the article, approval of the article; Semir Mehović, concept/design, data collection, data analysis/interpretation, statistics, approval of the article; Naida Omerović, concept/design, data analysis/interpretation, drafting the article, critical revision of the article, approval of the article; Anela Hadžifejzović-Trnka, Nermina Žiga-Smajić, Belma Pehlivanović and Dina Lagumdžija, data analysis/interpretation, critical revision of the article, approval of the article.

\section{Hosted file}

Main text file - Role of a pharmacist in the safe self-medication - a questionnaire-based survey.docx available at https://authorea.com/users/348029/articles/473513-role-of-a-pharmacist-in-thesafe-self-medication-a-questionnaire-based-survey

\section{Hosted file}

Table 1.docx available at https://authorea.com/users/348029/articles/473513-role-of-apharmacist-in-the-safe-self-medication-a-questionnaire-based-survey

\section{Hosted file}

Table 2.docx available at https://authorea.com/users/348029/articles/473513-role-of-apharmacist-in-the-safe-self-medication-a-questionnaire-based-survey

\section{Hosted file}

Table 3.docx available at https://authorea.com/users/348029/articles/473513-role-of-apharmacist-in-the-safe-self-medication-a-questionnaire-based-survey

\section{Hosted file}


Table 4.docx available at https://authorea.com/users/348029/articles/473513-role-of-apharmacist-in-the-safe-self-medication-a-questionnaire-based-survey
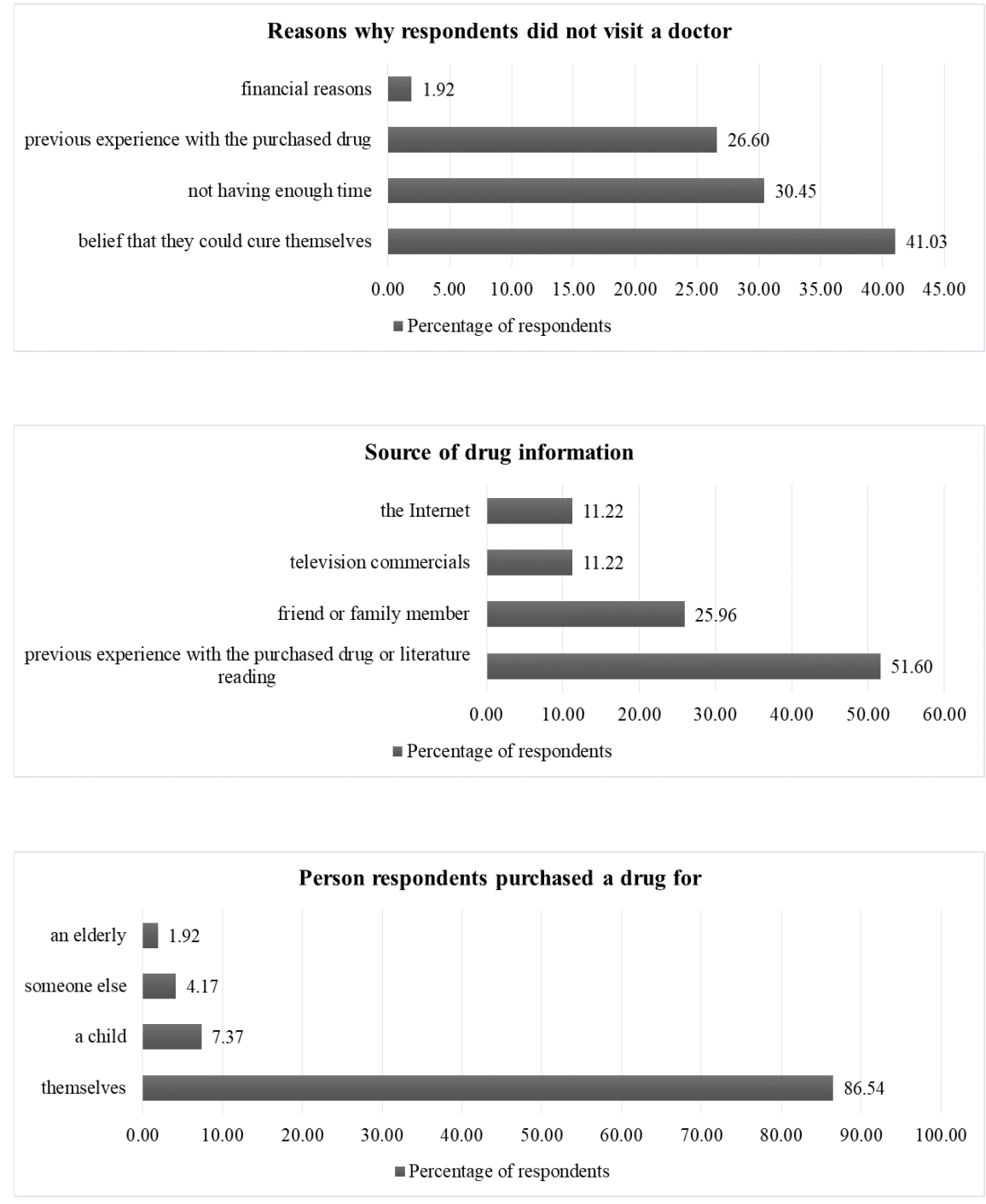

Time a pharmacist spent in a conversation with respondents

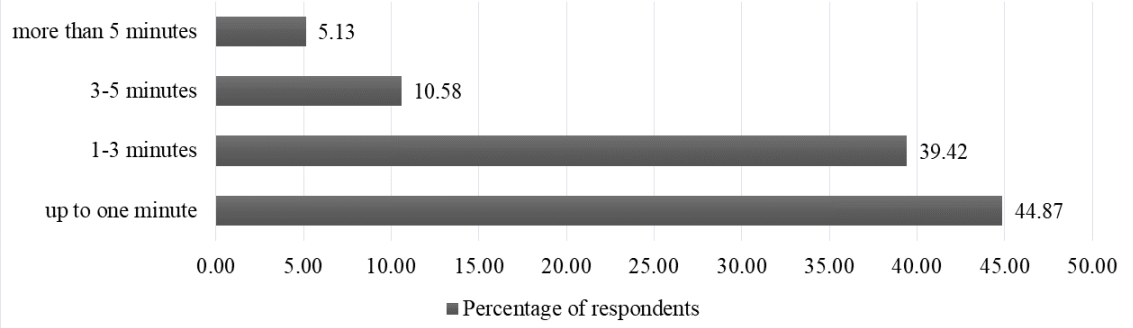

